\title{
Epstein Syndrome
}

National Cancer Institute

\section{Source}

National Cancer Institute. Epstein Syndrome. NCI Thesaurus. Code C131639.

An autosomal dominant disorder characterized by thrombocytopenia, giant platelets,

nephritis, and deafness; it is associated with mutation of the MYH9 gene. 